\title{
Queer Pedagogy in Sex Education
}

\author{
George Drazenovich \\ Lakehead University
}

\begin{abstract}
While increased visibility of gay, lesbian, transgendered, and queer people in public settings, including schools, is certainly freeing for many students, critical questions concerning whether popular media depictions of LGBTQ identities serve to liberate students, or instead facilitate subtle strategies of containment and ghettoizing, are being raised. The present article argues that as a sex education strategy, the essentializing of sexual identity within sex education should be supplanted by more constructivist approaches; ones that allow for maximum individuation and self-expression. Rather than embracing particular labels and the commodification that sometimes flows from them in the popular media landscape, queer-positive sex educators might consider adopting some methods associated with spiritual pedagogy to assist students in rethinking questions of sexuality and creating new possibilities for identities and creative self-expression.
\end{abstract}

Keywords: sex education, LGBT, queer, spiritual pedagogy, identity

\section{Résumé}

Si la visibilité des personnes LGBTQ dans la sphère publique, notamment dans les établissements d'enseignement, est certainement libératrice pour bien des élèves, il n'en 
demeure pas moins qu'on se demande si la représentation des identités LGBTQ dans les médias populaires sert à libérer les élèves ou si elles ne favorisent pas plutôt des stratégies subtiles de contrôle et de ghettoïsation. Le présent article soutient qu'en tant que stratégie d'éducation sexuelle, l'essentialisation de l'identité sexuelle dans le cadre de l'éducation sexuelle devrait être supplantée par des approches plus constructivistes laissant place à un maximum d'individualisation et d'expression de soi. Plutôt d'adopter certaines étiquettes et la marchandisation qui parfois en dérive dans les médias populaires, les éducateurs sensibles à l'allosexualité pourraient penser à certaines méthodes associées à la pédagogie spirituelle afin d'aider leurs élèves à repenser les questions relatives à la sexualité et à créer de nouvelles possibilités en matière d'identité et d'expression de soi.

Mots-clés : éducation sexuelle, LGBT, allosexuel, pédagogie spirituelle, identité 


\section{Introduction}

While increased visibility of gay, lesbian, transgendered, and queer people in public settings, including schools, is certainly freeing for many students, critical questions concerning whether popular media depictions of LGBTQ identity serve to liberate people, or instead facilitate subtle strategies of containment and ghettoizing, are being raised. Guidotto (2006), for example, argues that LGBTQ people "must proceed with caution when digesting this increased visibility in the media and consumer culture" (p. 3).

[Today homosexuality] conjures images of gay men toting GAP bags, wearing Prada shoes and redecorating some hopelessly unfashionable straight guy's apartment while giving him a personal makeover - and you can watch it all unfold weekly on the boob tube (Queer Eye for the Straight Guy). Plus, you can shop where the queer guys shop and buy the stuff the queer guys buy since all the corporate logos are prominently displayed and promoted on the show. Talk about flaunting it. The gay, white, youthful male has become (or arguably has always been, he is just more visible now) the frontline gay representative. He is ushering in the next phase of gay liberation, complete with increased media attention...I call it the McQueer phase. (Guidotto, 2006, p. 2)

While it is true that schooling should be, as McLaren (2009) argues, a process of understanding how multiple levels of identities are produced, sexuality cannot be fully considered without an awareness of how heteronormativity functions in the educational setting (Naidoo, 2007). This is particularly true in the area of identity formation. As Foucault (1997) observes:

If identity becomes the problem of sexual existence, and if people think they have to "uncover" their "own identity" and that their own identity has to become the law, the principle, the code of their existence; if the perennial question they ask is "Does this thing conform to my identity?" then, I think, they will turn back to a kind of ethics very close to the old heterosexual virility. If we are asked to relate to the question of identity, it has to be an identity to our unique selves. But the relationships we have to have with ourselves are not ones of identity; rather they must be relationships of differentiation, of creation, of innovation. (p. 166) 
In this article I argue that as a long-term strategy, educators need to find ways to deconstruct sexual identities through a critical educational process that provides students with a means of interpreting sexual identity more fluidly and broadly sensitive to media misrepresentation. Bragg (2006) argues that teachers fear too much that sex education might be "inappropriate" or "too explicit" and consequently do not offer young people experience or skills in critical media consumption. Explicit and inappropriate information is undoubtedly accessible and pervasive in television, Internet, advertising, and magazines. "Youth are then left to negotiate sexual media culture and become participants in this 'private' sphere that is less objective and more objectifying” (Ninomiya, 2009, p. 5). Constructing sexual identity in light of these influences is challenging and requires a clear pedagogical approach to sexual identity formation and the present articles proposes one direction.

As Hammack (2005) explains, theories around sexual identity take two forms: essentialist and social constructionist. Sex education that assumes an essentialist perspective views sexual identity as an internal property of individuals that transcends history and culture. In the essentialist frame, sexual identity is an "ahistorical, universal, context-independent, underlying trait of the individual (DeLamater \& Hyde, 1998)... Context matters to the essentialist only as it constrains, prohibits, or facilitates phenotypic expression" (Hammack, 2005, p. 270). Social constructionism, by contrast, argues that sexual identities are "products of particular historical and cultural understandings rather than being universal and immutable categories of human experience" (Bohan, 1996, p. xvi, cited in Hammack, 2005). Rather than embracing particular essentialist sexual labels and the commodification that has flowed from them in the media landscape, sex educators might consider embracing queer education as a pedagogy that will assist in rethinking questions of sexuality and creating the space for free exploration of the construction of the self. "Queer" is not an identity per se, "it is an analytic and political process aimed at subverting and potentially eliminating dichotomous sexual and gender constructs" (Schriver, 2011, p. 267).

Queer theory "looks with skepticism at the processes of how identities are constructed, and, in this way, learning becomes a way of risking the self as much as it does constructing the self" (Luhmann, 2009, p. 122). As Ford (2004) finds, many academics view queer theory as a tool for framing educational approaches and practices known as queer pedagogy (Britzman, 1995; Britzman, 1998; Butler, 1999; Elder, 1999; 
Kopelson, 2002; Sumara, 2001). Zacko-Smith and Smith (2010) argue that a major misunderstanding about queer theory is that it is the same as gay and lesbian studies. While queer theory is strongly associated with gay and lesbian studies, as well as feminism, ultimately, queer theory asks that educators help expose the "rigid normalizing categories" and expand them "beyond the binaries of man/woman, masculine/feminine, student/teacher, and gay/straight" (Meyer, 2007, p. 15). The problem is that "little work has been done to systematically identify pedagogical approaches and practices... around incorporating Queer theory into curriculums and activities" (Ford, 2004, p. 2). Britzman (1995) notes that queer pedagogy is concerned with deconstructing normalcy. By extension, this deconstruction of normalcy includes processes of caricatures of LGBTQ identity that occur through the media and popular culture. Queer pedagogy is thus well-suited to address the challenges surrounding consumer images of gay and lesbian identity that Guidotto (2006) and Ninomiya (2009) outline above.

\section{Queering Sexuality}

The "queering" of sexuality involves interpreting human sexuality politically, socially, and culturally, and subverting dominant discourses from a poststructural educational standpoint. Poststructural analysis is one of the main philosophical foundations supporting queer education today (Butler, 1999; Namaste, 1994; Pećić, 2006; Turner, 2000). Turner (2000) bluntly states, "poststructuralism is queer" and Pećić (2006) observes that "[to] chart all the many theorists and philosophers of the twentieth century whose work is related to and partially responsible for the queer investigations of sexuality is impossible. Poststructuralists, however, were especially influential" (p. 2).

The French poststructuralists' critical approach to sexual, essentialist identity was evident in the challenge of the privileging of masculinity in modern, Western culture (Pećić, 2006). Indeed, one of the first feminists who advanced an alternate means to interpret sexual identity was Irigaray (1985b). Her deconstruction of the category of "woman" as a marker of identity can be instructive for LGBTQ identity as well. Irigaray launched a sustained, critical analysis against Freud and his sexualized theory that posits female identity as a "lack" and as "other" than the male identity, which he presumed to be normative. In this kind of Freudian heterosexual frame of reference, the economy 
becomes one where males are the "producer, subjects, and agents of exchange" and the females are the "commodities" (Irigaray, 1985b, p. 192). In a similar fashion, heteronormativity in culture also produces commodification of non-heterosexuals. Irigaray's solution was not to create an alternative theory of an essentialized definition of "woman," nor did she suggest a reversal of the binary structure of male/female to female/male. Irigaray (1985b) writes:

[F]or woman it is not a matter of installing herself within this lack, this negative, even by denouncing it, nor of reversing the economy of sameness by turning the feminine into "the standard for sexual difference," it is rather a matter of trying to practice that difference [italics in original]. (p. 159)

For Irigaray, "woman" signifies the possibility of never being simply one; hence the apt title of her follow-up book from Speculum of the Other Woman (1985a), entitled This Sex which Is Not One (1985b). In a similar way, queer pedagogy can also serve to articulate identity in a way other than becoming locked into a hetero/homosexual binary. Sexual identity, within queer education, is a heterogeneous and incomplete process and any "temporary coherence into seemingly solid characteristics or structures is only one of subjectivity's many possible expressions. What felt solid and real may subsequently separate and reform" (Flax, 1993, p. 94). First, though, sexuality, as we have come to understand that term today, needs to be deconstructed before we can begin to think inclusively, and outside of strict binary categories.

\section{Deconstructing Homosexuality}

As a historical matter, Foucault suggests that in the Western world, sexuality as a political, medical, and judicial discourse accelerated in the 18th and 19th centuries (Drazenovich, 2010). To Foucault and other critical theorists, the word sexuality is not an ahistorical phenomenon but is, rather, a historical neologism. The term was reinterpreted in the nineteenth century in connection with other scientific developments including advancements in understanding human reproduction (biology), and the emergence of the new social sciences of psychology and sociology (Foucault, 1990b). The use of the term sexuality signalled change in the way individuals were led to assign meaning and value to their conduct, the orientation of their desires, and their identity (Foucault, 1990b). 
The term discourse has a specific meaning in Foucault's method and occupies a central place in approaching interpretive issues related to sexuality in queer theory. Discourses are social, political, and cultural arrangements of ideas and concepts through which the world as we know it is communicated and constructed. Discourse is about the production of language and practices by particular systems that produce existential meanings that then shape our individual lives. Discourses can be distinguished from any type of utterance. For an utterance to be described as a discourse, in the way queer theorists use the term, that discourse must be accompanied by force of governmental law or policy that can influence the public. That is the power side of the discourse. The discourse must also be supported by a form of knowledge that the community recognizes as authoritative; generally this means discourses are supported by appeal to either social or natural scientific methods, or increasingly media and advertising representations. That is the knowledge side of the discourse. The stronger the nexus between power and knowledge that is inherent in the discourse, the greater is its impact (Foucault, 1980). Sex education curricula, for example, is one type of discourse advanced by those in positions of governmental power, in this instance Canadian ministries of education, and delivered at the level of classroom instruction by teachers.

As Foucault (1990a) clearly outlines at the beginning of his first volume in The History of Sexuality, "the primary issue with respect to sexuality is to account for the fact that it is spoken about, to discover who does the speaking, the positions and viewpoints from which they speak and the institutions which prompt people to speak about it" (p. 11). At issue, according to Foucault, is the overall "discursive fact; the way in which sex is "put into discourse"" (1990a, p. 11). His method is to locate the forms of power, the channels it takes, and the discourses it permeates in order to reach individual modes of behaviour.

It is important to appreciate that what is constitutive in sexuality is the social and political action that divides sexuality, as a particular form of knowledge (a science), from sex as a human activity. Sexual identity is the name given to a particular historical construction. It is this action - namely, the conceptual constructions propagated by particular institutions (i.e., the discourses) - that have shaped our perceptions of sexual identity. As Halperin (1998) observes, "these strategies took the form of establishing norms of self-regulations, not by punishing deviations from what was interpreted as natural but by constructing new species of individuals, discovering and implanting perversions, and 
thereby elaborating more subtle and insidious means of social control" (p. 98). Indeed, it was against the emergent 19th century cultural and scientific background that the newly developed medical category of the homosexual came into existence. Foucault (1990a) writes:

We must not forget that the psychological, psychiatric, medical category of homosexuality was constituted from the moment it was characterized-Westphal's famous article of 1870 on "contrary sexual sensations" can stand as its date of birth-less by a type of sexual relationship than by a certain quality of sexual sensibility, a certain way of inverting the masculine and feminine in oneself. Homosexuality appeared as one of the forms of sexuality when it was transposed from the practice of sodomy onto a kind of interior androgyny, a hermaphrodism of the soul. The sodomite had been a temporary aberration; the homosexual was now a species. (p. 43)

Westphal was influenced by Ulrich (1994), who in 1864 was the first to come up with a scientific theory of homosexuality. Ulrich's writings, The Riddle of the Man-Manly Love, gave rise to the paradigm of sexual inversion which became the dominant scientific paradigm which structured most 19th century theories of homosexuality (Terry, 1999). Ulrich believed that sexual attraction to men was fundamentally female in nature. Thus, males who were attracted to the same sex had a male body but their psyche was inverted as female. Ulrich believed that homosexuality was an inborn trait and posited the existence of a third sex to explain it. Foucault highlights Westphal's (1870) publication in German, Contrary Sexual Feeling, as "emblematic of the way in which homosexuality began to be discretely categorized and implanted in bodies" (Drazenovich, 2010, p. 10). These scientific discourses on sexuality began to contact specific bodies, intensify areas of sexual desire as meaningful markers of identity, dramatize key moments of psychosexual development as being pivotal in homosexual development, and wrap the human body in its totalizing sexual embrace (Foucault, 1990a). Irrespective of the liberatory intent of Ulrich and Westphal, the ultimate effect of medicalizing and making homosexuality a species was that it made homosexuality analytically visible as a pathology, an anomaly, a third sex, an inverted nature. Homosexuality was implanted in bodies to provide a principle of scientific intelligibility which could be managed under a psychiatric mandate that continued all the way up to 1987. 
Through the creation of homosexual populations, individuals were subject to strategies of containment. "The pathologization of homosexuality and the creation of a homosexual population created a dynamic in which individuals began a process of self-interrogation by accounting themselves as an anomaly and then seeking help in the very system that created it" (Drazenovich, 2010, p. 10). Halperin (1998) agrees that "sexuality takes on new social and individual functions, and assumes a new importance in defining the modern self since the 19th century" (p. 96). With homosexuality medicalized in the 19 th century, it no longer was solely understood as a transgression from a moral code or a forbidden act. It remained all of that and more. Homosexuality became essentialized as a medically and psychologically grounded ontological identity. As Foucault (1990a) writes:

The nineteenth century homosexual became a person, a past, a case history and a childhood...Nothing that went into his composition was unaffected by his sexuality. It was everywhere present in him... It was consubstantial with him, less habitual sin than a singular nature. (p. 43)

Current shifts and challenges. The educational challenge today is "how might curriculum begin to assert itself into the tangled web of ignorance that currently exists in and around discourses about sexuality?" (Sumara \& Davis, 1999, p. 200). A queer pedagogy, insofar as it is concerned with questioning identity as opposed to fixing identity, can assist in students asking different questions around sexuality, and therefore finding different answers to such complex questions. As Ninomiya (2009) writes, "Questioning sexual and gender identity is not only complex but can also challenge the very core of what it means to align oneself with a certain category" (p. 6). Similarly, gender and sexual identities are complicated by politics, religion, and stereotypes. In the context of sex education, Naidoo (2007) argues that “'queer' theory does not label gays and lesbians as such. Rather, it posits all sexualities, which include bisexual and transgendered people, into the encompassing category of 'queer' (Hall, 2003; Loutzenheiser \& MacIntosh, 2004; Lugg, 2003)" (p. 3). Such a view underpins and eliminates heteronormativity within the sex education curricula (Naidoo, 2007).

According to Talburt and Rasmussen (2010), an emerging area in queer education is "after-queer." Their scholarship is not suggesting that queer theory is passé; instead, they write, “...the 'after-queer' that we refer to in the title of this paper speaks to these 
repetitions and linearities that tend to frame queer research....as the end-point of a particular style of thought... We strive to imagine different trajectories that queer research might create" (p. 12). One of those different trajectories that I suggest in this article is joining queer theory with another emerging trend in education, namely, spiritual pedagogy. The convergence of these two directions has the potential to produce an effective form of sex education pedagogy. Such pedagogy is consistent with traditional First Nations' understanding of LGBTQ identity as "two-spirited." The term two-spirited reflects the Indigenous worldview around interpreting sexual identity as "spirit." Anguksuar (Richard LaFortune) explains that "niizh manitoag (two-spirits) indicates the presence of both a feminine and a masculine spirit in one person" (1997, p. 221). Like the term queer, two-spirited is meant to be inclusive, ambiguous, and fluid (Driskill, 2010). There is compelling evidence that this kind of gender identity existed in almost 155 tribes in North America pre-contact (Roscoe, 1988). Further, some transgendered researchers have also identified the transitioning process as a spiritual one. Dollarhide (2003), for instance, argues that being transgendered is a spiritual phenomena and not a psychological one. Jordan (2012) quotes Dollarhide (2003) in support of her experience, writing "that for the trans person being true to their own originality is a spiritual issue because it is the way in which (they) physically embody the spiritual truths within them" (n.p.).

The use of the term "spiritual" is not intended to de-politicize identity to a purely interior, non-public space. As the Russian philosopher and theologian Berdyaev (1948) wrote, "Bread for myself is a material question, but bread for my neighbour is a spiritual one" (p. 184). Nor should the term spirituality be conflated with religion. As Wright (2000) notes, renewed scholarly interest in spirituality is too diverse and deeply rooted to be conflated with religion or the rise of religious fundamentalism in some religious traditions. Kidd (2007) argues that one of the consequences of the separation between sexual identity and spirituality is that people are more inclined to perceive the meaning of the "I" and the body as separate entities, "when in reality no separation exists between 'me' and 'my body.' The human person is an embodied consciousness; an incarnated subject" ( $p$. 4). Finally, as I will argue below, Foucault envisioned spirituality as inherently implicated in identity formation and critical of the development of embodied subjectivities in ancient Greek sex education. 


\section{Queer Theory in Sex Education}

Queer theory is establishing itself in education as an analytic framework. Ford's (2004) research article "Queering Education from the Ground Up: Challenges and Opportunities for Educators" is a valuable resource and analysis of the contribution queer theory can make to sex education. Zacko-Smith and Smith (2010) argue that "sexual orientation and gender/gender-identity issues have evolved from the simple fight for acceptance prevalent in the 1960s through the 1980 s, to a burgeoning redefinition of sexual identity and sexuality itself" (p. 3). Queer theory "is an important extension of critical pedagogy, social constructionism, postmodern feminism, and liberatory/emancipatory education" (ZackoSmith \& Smith, 2010, p. 8). Educators can find a very approachable examination of the history and implications of queer theory, as well as various interpretations that surround it in Rodriguez and Pinar's (2007) Queering Straight Teachers: Discourse and Identity in Education. Misawa (2010) explores how racism and heterosexism influence society and education and then joins critical race theory and queer theory, developing queer race pedagogy for educators. Smith (2012) explored the potential and fruitful relationship between queer theory and media literacy in a workshop. His findings were published in the Canadian Federation for the Humanities and Social Sciences bulletin on equity issues related to LGBTQ people. In that workshop, "he sought to enable future secondary school teachers to conceive of an anti-homophobic pedagogy that was accessible to teens and that encouraged their students to think critically." Meiners and Quinn (2012) edited a series of reflective essays entitled Sexualities in Education: A Reader, the theme of which was sexualities in a classroom setting. "With over sixty contributions divided into nine sections, Sexualities in Education provides dissonant perspectives from educators, activists, artists, and researchers. In this self-proclaimed 'queer-centric' text, most of the volume's contributions focus on issues specific to young lesbian, gay, bisexual, and queer individuals" (Samayoa, 2013, p. 414). 


\section{History of Queer Theory in Sex Education}

Queer education is heavily influenced by Foucault and his History of Sexuality. Explaining queer studies and its approach to sexuality as an identity, Kelly (2009) observes:

Foucault argues that it is not the proliferation of identities that leads to sexual liberation but, rather, the separation of acts and feelings from those identities. Instead of claiming an identity for one's desires and acts, Foucault favors using one's desires to create new pleasures, relationships, networks, and cultural and political practices. In other words, it will be liberatory to simply desire, feel, and act, to just be sexual, rather than to attach those behaviors to larger cultural meanings. (para. 13)

Foucault (1990b) explains the act of identity formation as:

those intentional and voluntary actions by which individuals not only set themselves rules of conduct, but also seek to transform themselves, to change themselves in their singular being, and to make their life into an oeuvre that carries certain aesthetic values and meets certain stylistic criteria. (p. 10)

To make one's life into an oevure means to make one's very life into an art. Identity formation, therefore, within a queer paradigm, is a more artistic, internal, and reflective process, and less focused on social and cultural prescriptions around gender or sexual identity labels.

A benefit to a queer approach to sex education was provided by Foucault when he compared the ancient Greek approach to sex education to the modern one. The criterion by which sex education was measured in ancient Greece was that the individual fulfilled themselves as an "ethical person by shaping a precisely measured conduct that was plainly visible to all and deserving to be long remembered" (Foucault 1990b, p. 91). Most sex educators would probably agree that if students could come away with this kind of identity formation, the education would have been successful. The core question is: what would such a curriculum look like?

Joining Queer theory and spiritual pedagogy. Farrelly, O’Brien, and Prain (2007) suggest that "a discursive emphasis on prohibition and risk, or rational autonomous control and 'adult' management of sexuality, could be tempered by a focus on 
emotional maturational issues and reflection on affective dimensions of this subject as lived and felt by learners" (p. 78). Talburt and Rasmussen (2010) write that "Mayo (2007) marks a movement from a focus in the 1990s on gender bias, gender roles, and heterosexism as they sustain homophobia to a focus in the 2000s on challenging tropes of wounded identities, or gay youth as victim, to underscore queer youth agency and creativity" (p. 4). A queer pedagogy in sex education, therefore, would not be entirely risk management and disease prevention, themes that currently pervade most sex education curricula. Instead, queer pedagogy could augment the current sex education curricula by teaching the process of identity formation through procedures that the ancient Greeks referred to as the care of the self (i.e., spirituality).

What seemed to be the object of reflection for the Greeks in matters of sexual conduct was not the act itself, or its forms (i.e., sexual "orientation"), it was, rather, with what force is one transported by the aphrodisia (Foucault, 1990b)? As Foucault (1990b) defines it, "the aphrodisia are the acts, gestures and contact that produce certain forms of pleasure" (p. 40). These differences had considerable importance in how one understood and cared for oneself as subject of sexual desire. For the ancient Greeks, the "use of pleasures" (chresis aphrodision) was formulated around key axes of experience, including the person's relation to one's body, the person's relation to vital intimate relationships, and the person's relation to truth (Foucault, 1990b). There was no one single overall system of sexuality that imposed itself on all people in the same way and classified acts in terms of their being natural or unnatural, pathological, or normal. While there were a few precepts related to moderation and self-control which applied more broadly to all areas of life, "standards of sexual morality were always tailored to one's way of life, which was itself determined by the status one had inherited and the purposes one had chosen" (Foucault, 1990b, p. 60). Britzman (1996) suggests that schools and students need to view sex education as indistinguishable from this ancient Greek concept of the care of the self.

It is appropriate to refer to the ancient Greek concept of the "care of the self" as a spiritual process. Cottingham (2003), for example, argues that "the idea of care of the self, though it clearly does not exhaust the domain of the spiritual, does seem to capture an important part of what most people understand by it" (p. 43). Discussing the ancient Delphic dictum "know thyself," which Socrates was drawn to, Cottingham (2003) adds that "it is difficult to read what Socrates says about his inner voice, about the search for purity of conscience and integrity, without seeing the 'examination' he advocates 
as indeed possessing the 'spiritual' dimension identified by Foucault" (p. 41). Foucault (2001) interprets the ancient Greek care of the self to what we might refer to today as a spiritual process:

We will call "spirituality" then the set of these researches, practices, and experiences, which may be purifications, ascetic exercises, renunciations, conversions of looking, modifications of existence, etc., which are, not for knowledge but for the subject, for the subject's very being, the price paid for access to the truth. (p. 15)

Thus, sex educators may be able to draw on the research of scholars in spiritual pedagogy as a means to facilitate a queer approach to identity formation. Wright argues that at the heart of critical spiritual pedagogy stands the search for ultimate meaning and truth. In this sense spiritual pedagogy is an important corollary to queer education. According to Wright (2000), spiritual pedagogy "balances a hermeneutic of nurture with a hermeneutic of critical thinking" (p. 139). Ryoo, Crawford, Moreno, and McLaren (2009) have introduced the idea of critical spiritual pedagogy by building on the rich theoretical tradition of critical theory and critical pedagogy. Ryoo et al. (2009) explain:

Critical spiritual pedagogy is a method of teaching and learning that is rooted in three central concepts: spirituality, humanity, and power. It acknowledges the way student and teachers are exploited, fragmented, and Othered in schools while advocating for curricular and educational practices that are based in love and integrity. (p. 132)

In their article "Critical Spiritual Pedagogy: Reclaiming Humanity through a Pedagogy of Integrity, Community and Love," Ryoo et al. (2009) discuss the implication that critical spiritual pedagogy has for educational practice, national curriculum, and education research and policy. "Theorists and researchers offer that (successful sex education) not only troubles the concept of gender identity but also questions the root of fear when one talks about multiple sexualities - providing youth with skills and language to negotiate their way through the process of identity formation" (Ninomiya, 2009, p. 6). For spiritual pedagogy, to ensure that the knowledge does not become simply affective but also has an effect in their concrete lived experience, the practice of "grounding spiritual knowledge practically" is important to ensure that the "knowing" that arises through education assists students in "the practicality of their daily lives, as well as an awakened desire 
to connect with the world at large and respond to its many needs creatively" (Miller \& Athan, 2007, p. 31). From this perspective the classroom is conceptualized as a holding environment, or container, in which new possibilities of identity and expression can be invoked, beheld, and related to.

With revisions to sex education curricula being contemplated in various Canadian jurisdictions, spiritual pedagogy might help in shaping a queer sex education curriculum that could advance values such as equity, diversity, and understanding, along with imbuing students with critical values of critical thought and analysis. Research and practical means to incorporate a spiritual pedagogy in sex education is emerging. Clark and Clark (2004) have developed a pedagogical technique aimed at secondary-school-aged students. The objectives are "to identify at least two aspects of spirituality and sexuality, explain how spirituality and sexuality are similar, and recognize connections between one's spiritual self and sexual self" (Clark \& Clark, 2004, p. 31). They conclude that their technique is holistic and at the end of the exercise, sexuality becomes more than sex, and spirituality become more than religion. Students should begin to realize an intertwining perspective that, when recognized, may lead to a deeper understanding of how identities are formed and their fluid properties.

\section{Conclusion}

Queer pedagogy is in no way intended to displace LGBTQ advocacy efforts, or GSA (Gay-Straight Alliance) efforts and movements in schools. The queer pedagogical contribution to the LGBTQ movement lies in unmasking and undermining disguised and evident forms of domination that are embedded in scientific knowledge and the media landscape. This critical component of queer pedagogy is an important contribution to sex education. The force of medicalized discourses of homosexuality can be blunted through critique. Indeed, as Feder (2009) writes, “in Foucault's own work of course, 'the homosexual' is the exemplary model of how a category of identity can be deployed to 'define and subject' individuals, but it was also by means of this category that a resistance movement, 'gay liberation' was born" (p. 134). As educators and advocates, we need to be cautious of how identity can serve heteronormative ends and subtly marginalize LGBTQ people. The process of identity formation is lifelong, ongoing, creative, and innovative. 
Educators require a pedagogy that can assist in facilitating this process. For this article, I argue that joining with those scholars who approach sex education as indistinguishable from the care of the self is a direction that sex educators might consider. Foucault, who is considered one of the leading pioneers of queer theory, argues that historically, the care of the self is a spiritual process. Besley (2005) adds that Foucault's model of the care of the self in relation to practices of freedom as outlined in The History of Sexuality provides a pedagogical approach that offers schools an ethically suitable way of dealing with the identity formation. I have argued that the care of the self can be interpreted as a spiritual process and that sex education can be widened to include spirituality. Spiritual pedagogy has been able to balance critique with nurture, and in this way can be used as an ally and vehicle for queer pedagogy. As Kidd (2007) writes, "Spirituality and human sexuality can be understood as life projects, as something which leads to a deeper discovery of self' (p. 9). It is evident that more research and development is required to sharpen queer pedagogy and provide a means for students to reflect on as they work through the enigma of sexual identity. The vast majority of the literature that exists on the subject of spiritual pedagogy is less than 10 years old and queer pedagogy is still relatively new. However, I have argued that inasmuch as there is synergy between these two pedagogies, more sustained research can and should happen in order to create a more critical, inclusive, open, and equitable sex education. 


\section{References}

Anguksuar/LaFortune, R. (1997). Postcolonial colonial perspective on western [mis] conceptions of the cosmos and the restoration of Indigenous taxonomies. In $\mathrm{S}$. Jacobs, W. Thomas, \& S. Lang (Eds.), Two-spirit people: Native American gender identity, sexuality, and spirituality (pp. 217-222). Urbana, IL: University of Illinois Press.

Berdyaev, N. (1948). The origin of Russian communism (R. M. Frency, Trans). Glasgow, Scotland: The University Press.

Besley, T. (2005). Foucault, truth telling and technologies of the self in schools. Journal of Educational Enquiry, 6(1), 76-89.

Bohan, J. S. (1996). Psychology and sexual orientation: Coming to terms. New York, NY: Routledge.

Bragg, S. (2006). Young women, the media, and sex education. Feminist Media Studies, 6(4), 546-551.

Britzman, D. (1995). Is there a queer pedagogy? Or, stop reading straight. Educational Theory, 45(2), 151-165.

Britzman, D. (1996). On becoming a "little sex researcher": Some comments on a polymorphously perverse curriculum. Journal of Curriculum and Teaching, 12(2), 4-11.

Britzman, D. (1998). Lost subjects, contested objects: Toward a psychoanalytic inquiry of learning. Albany, NY: State University of New York Press.

Butler, J. (1999). Gender trouble: Feminism and the subversion of identity. New York, NY: Routledge, Chapman \& Hall.

CBC. (2007, 2, March). Same sex rights: Timeline. In Depth. Retrieved from the CBC website: http://www.cbc.ca/news/canada/ $\underline{\text { timeline-same-sex-rights-in-canada-1.1147516 }}$

Clark, S., \& Clark, J. (2004). Spirituality and sexuality: Compatible components for optimal health. Journal of School Health, 74(1), 30-31. 
Cottingham, J. (2003). Spirituality, science and morality. In D. Carr \& J. Haldane (Eds.), Spirituality, philosophy and education (pp. 40-54). London, England: RoutledgeFalmer.

DeLamater, J. D., \& Hyde, J. S. (1998). Essentialism vs. social constructionism in the study of human sexuality. Journal of Sex Research, 35(1), 10-18.

Dollarhide, K. (2003). The heart/spirit, not the head/mind: Being transgendered is a spiritual phenomena and not a psychological condition. Presented at the Sixth International Congress on Sex and Gender Diversity, Manchester Metropolitan University.

Drazenovich, G. (2010). A Foucauldian analysis of homosexuality. Educational Philosophy and Theory, 42(6), 1-17.

Driskill, Q. (2010). Double-weaving two-spirit critiques: Building alliance between native and queer study critiques. GLQ; A Journal of Lesbian and Gay Studies, 16(1-2), 69-92.

Elder, G. S. (1999). Queerying boundaries in the geography classroom. Journal of Geography in Higher Education, 23(1), 86-93.

Farrelly, C., O’ Brien, M., \& Prain, V. (2007). The discourses of sexuality in curriculum documents on sexuality education: An Australian case study. Sex Education, 7(1), 63-80.

Feder, K. (2009). A review: Margaret A. McLaren [Review of the book: Feminism, Foucault, and embodied subjectivity]. Foucault Studies, No. 6, 131-135.

Flax, J. (1993). Disputed subjects: Essays on psychoanalysis, politics and philosophy. New York, NY: Routledge.

Ford, T. (2004). Queering education from the ground up: Challenges and opportunities for educators. Canadian Online Journal of Queer Studies in Education, 1(1), $1-28$.

Foucault, M. (1980). Power/knowledge. In C. Gordon (Ed.), Selected interviews and other writings 1972-77. (C. Gordon, L. Marshall, J. Mepham, \& K. Spoer, Trans.) (pp. 187-200). New York, NY: Pantheon Books. 
Foucault, M. (1990a). The history of sexuality: Vol. 1. An introduction. (R. Hurley, Trans.) New York, NY: Vintage Books. (Original work published in 1978)

Foucault, M. (1990b). The history of sexuality: Vol. 2. The use of pleasure. (R. Hurley, Trans.). New York, NY: Vintage Books. (Original work published in 1985)

Foucault, M. (1997). Ethics: Subjectivity and truth. (R. Hurley, Trans.). New York, NY: New York Press.

Foucault, M. (2001). The hermeneutics of the subject: Lectures at the Collége de France, 1981-82. (F. Gros, Ed.; G. Burchell, Trans.) NewYork, NY: Palgrave Macmillan.

Fox, R. E. (1988). Proceedings of the American Psychological Association, Incorporated, for the year 1987: Minutes of the annual meeting of the council of representatives. American Psychologist, 43(7), 508-531.

Guidotto, N. (2006, May 5). Cashing in on Queers: From liberation to commodification. Canadian Online Journal of Queer Studies in Education [Online], 2(1). Available: http://jqstudies.library.utoronto.ca/index.php/jqstudies/article/view/3286/1414

Hall, D. E. (2003). Queer theories. New York, NY: Palgrave Macmillan.

Halperin, D. (1998). Forgetting Foucault: Acts, identities, and the history of sexuality. Representations, 63, 93-120.

Hammack, P. (2005). The life course development of human sexual orientation: An integrative paradigm. Human Development, 48(5), 267-290.

Irigaray, L. (1985a). Speculum of the other woman. (G. Gill, Trans.) Ithaca, NY: Cornell University Press. (Original work published in 1974)

Irigaray, L. (1985b). This sex which is not one. (C. Porter with C. Burke, Trans.) Ithaca, NY: Cornell University Press. (Original work published in 1977)

Jordan (2012, July 14). Being transgendered is a ... [Blog post]. Retrieved from On Becoming website: http://onbecomingjordan.wordpress.com/2012/07/14/ being-transgender-is-a/

Kelly, R. (2009). Queer studies. In J. O’Brien (Ed.), Encyclopedia of gender and society (pp. 691-696). Thousand Oaks, CA: Sage Publications. 
Kidd, S. (2007). Paul Ricoeur on spirituality and sexuality. Inbetweeness. Retrieved from: http://www.inbetweenness.com/Sunnie's $\% 20$ Publications/PAUL $\% 20$ RICOEUR\%200N\%20SPIRITUALITY\%20AND\%20SEXUALITY.pdf

Kopelson, K. (2002). Dis/Integrating the gay/queer binary: Reconstructed identity politics for a performative pedagogy. College English, 65(1), 17-35.

Library of Parliament. (2005, September 14). Bill C-38: The civil marriage act. Retrieved from the Parliament of Canada website: http://www.parl.gc.ca/About/Parliament/ LegislativeSummaries/bills_ls.asp? $1 \mathrm{~s}=\mathrm{c} 38 \& \operatorname{Parl}=38 \& \mathrm{Ses}=1$

Loutzenheiser, L. W., \& MacIntosh, L. B. (2004). Citizenships, sexualities, and education. Theory into Practice, 43(2), 151-159.

Lugg, C. A. (2003). Sissies, faggots, lezzies, and dykes: Gender, sexual orientation, and a new politics of education? Educational Administration Quarterly, 39(1), 95-134.

Luhmann, S. (2009). Queering/querying pedagogy? Is a pretty queer thing. In W. Pinar (Ed.), Queer theory in education (pp. 120-132). Mahwah, NJ: Lawrence Erlbaoaum Associates.

Mayo, C. (2007). Queering foundations: Queer and lesbian, gay, bisexual, and transgender educational research. Review of Research in Education, 31(1), 78-94.

McLaren, P. (2009). Critical pedagogy: A look at the major concepts. In A. Darder \& A. Baltodano (Eds.), The critical pedagogy reader (2nd ed.) (pp. 61-83). New York, NY: Routledge Press.

Meiners, E., \& Quinn, T. (2012). Sexualities in education: A reader. New York, NY: Peter Lang.

Meyer, E. (2007). But I'm not gay: What straight teachers need to know about queer theory. In N. Rodriguez \& W. F. Pinar (Eds.), Queering straight teachers: Discourse and identity in education (pp. 15-32). New York, NY: Peter Lang.

Miller, L., \& Athan, A. (2007). Spiritual awareness pedagogy: The classroom as spiritual reality. International Journal of Children's Spirituality, 12(1), 17-35.

Misawa, M. (2010). Queer race pedagogy for educators in higher education: Dealing with power dynamics and positionality of LGBTQQ students of color. International Journal of Critical Pedagogy, 3(1), 26-35. 
Naidoo, L. (2007). Learning issues of sexuality, race, and power in the classroom. Electronic Journal for Inclusive Education, 2(1), 1-7.

Namaste, K. (1994). The politics of inside/out: Queer theory, poststructuralism, and a sociological approach to sexuality. Sociological Theory, 12(2), 220-231.

Ninomiya, M. (2009). Sexual health education: Silenced by diplomacy and political correctness. The Morning Watch: Educational and Social Analysis, 37(1-2), 1-9.

Pećić, Z. (2006). Queering queer theory: An analysis of Tony Kushner (Unpublished doctoral dissertation). University of Copenhagen, Copenhagen, Denmark.

Rodriguez, N., \& Pinar, W. (Eds.). (2007). Queering straight teachers: Discourse and identity in education. New York, NY: Peter Lang.

Roscoe, W. (1988). Living the spirit: A gay American Indian anthology. New York, NY: St. Martin's Press.

Ryoo, J., Crawford, J., Moreno, D., \& McLaren, P. (2009). Critical spiritual pedagogy: Reclaiming humanity through a pedagogy of integrity, community, and love. Power and Education, 1(1), 132-146.

Samayoa, A. (2013). Sexualities in the classroom and beyond. GLQ: A Journal of Lesbian and Gay Studies, 19(3), 414-416.

Schriver, J. (2011). Human behavior and the social environment: Shifting paradigms in essential knowledge for social work practice. Boston, MA: Ally \& Bacon.

Smith, C. (2012, February 22). How (not) to do queer studies in the classroom: Teaching to think beyond tolerance. Equity Matters. Federation for the Humanities and Social Sciences. Retrieved from Idées/Ideas website: http://www.idees-ideas.ca/ blog/how-not-do-Queer-studies-classroom-teaching-think-beyond-tolerance

Sumara, D., \& Davis, B. (1999). Interrupting heteronormativity: Toward a queer curriculum theory. Curriculum Inquiry, 29(2), 191-208.

Sumara, D. J. (2001). Queer theory and literacy education. English Quarterly, 33(3-4), 14-17.

Talburt, S., \& Rasmussen, M. L. (2010). “After queer” tendencies in queer research. International Journal of Qualitative Studies in Education, 23(1), 1-14. 
Terry, J. (1999). An American obsession: Science, medicine, and homosexuality in modern society. Chicago, IL: University of Chicago Press.

Turner, W. (2000). A genealogy of queer theory. Philadelphia, PA: Temple University Press.

Ulrich, K. (1994). The riddle of the man-manly love. (M. Lombardi-Nash, Trans.) Amherst, NY: Prometheus Books. (Original work published in 1864)

Westphal, C. (1870). Die conträre sexualempfindung. Archiv für Psychiatrie und Nervenkrankeiten. Vol. 2. Berlin: n.p.

Wright, A. (2000). Spirituality and education. New York, NY: Routledge Falmer.

Zacko-Smith, J., \& Smith, G. P. (2010). Recognizing and utilizing queer pedagogy: A call for teacher education to reconsider the knowledge base on sexual orientation for teacher education programs. Multicultural Education, 18(1), 2-9. 